\title{
CORPOS, AFETOS, SENSIBILIDADES E O SENTIMENTO DA
} HISTÓRIA $^{1}$

BODIES, AFFECTS, SENSIBILITIES, AND THE FEELING OF HISTORY

\section{Henrique Fernandes Antunes ${ }^{2}$}

Em dezembro de 2019, tivemos o prazer de receber Charles Hirschkind, professor do Departamento de Antropologia da University of California Berkeley, no Centro Brasileiro de Análise e Planejamento (CEBRAP). Sua primeira visita ao Brasil foi feita a convite do Projeto Temático Fapesp "Religiáo, Direito e Secularismo" (2015/02497-5). Na ocasiáo, realizamos um seminário interno e uma conferência aberta no CEBRAP ${ }^{3}$, bem como um evento na Universidade de Campinas, em parceria com o Laboratório de Antropologia da Religião (LAR). Antes de seu retorno aos Estados Unidos, tive, juntamente com Bruno Reinhardt e Eduardo Dullo, a oportunidade de realizar uma entrevista com nosso convidado, a qual integra o presente número da Debates do NER.

Somada à tradução do artigo The Ethics of Listening: Cassette Sermon Audition in Contemporary Egypt, a publicação da entrevista permite a todos atestar a relevância de seu pensamento e obras para o pensamento antropológico e para os estudos de religião contemporâneos. A tradução remete a um momento anterior de seu trabalho (o artigo foi originalmente publicado em 2001 na American Ethnologist), baseado em sua pesquisa no Egito, focada

${ }^{1}$ Como citar: ANTUNES. Henrique Fernandes. Corpos, afetos, sensibilidades e o sentimento da história. Debates do NER, Porto Alegre, ano 21, n. 39, p. 175-177, 2021.

2 Pós-doutorando pelo International Postdoctoral Program do Centro Brasileiro de Análise e Planejamento, Brasil. E-mail: hictune@yahoo.com. ORCID: https://orcid. org/0000-0002-4215-9314.

${ }^{3}$ A conferência está disponível na íntegra no canal do CEBRAP no YouTube, podendo ser acessada no link https://www.youtube.com/watch?v=NVlG0qWe4vk. 
na questão das novas tecnologias midiáticas e sua relação com o sensório, atentando para as formaçóes éticas e políticas que emergiam a partir dessa relação. Naquele momento, se tratava de explorar as formas pelas quais práticas e tradiçóes islâmicas foram revistas e, ao mesmo tempo, renovadas pelos novos meios de comunicação, assim como por novas configuraçóes da vida social e política no Egito.

A entrevista, por sua vez, além de retomar questóes e temas de seu primeiro trabalho, adentrou também os caminhos que culminaram em uma mudança de objeto e de temática em seu mais recente livro, The Feeling of History: Islam, Romanticism, and Andalusia (Hirschkind, 2020). Enquanto seu livro anterior, The Ethical Soundscape (Hirschkind, 2006), buscava apreender a relação entre novas mídias e o sensório para as práticas e ética religiosas, The Feeling of History nos convida a olharmos ao passado islâmico da Europa e aos modos pelos quais este insiste em habitar seu presente, pondo em xeque as narrativas que buscam assegurar uma identidade europeia marcadamente cristá.

Em uma perspectiva mais ampla, a entrevista apresenta não somente os temas de pesquisa que cativaram o antropólogo, mas oferece ao leitor uma espécie de inteligibilidade a posteriori dos caminhos que o levaram dos Estados Unidos ao Egito e, mais recentemente, à Espanha. No entanto, como nos lembra Bourdieu (1986), é necessário atentar para o fato de que todo relato autobiográfico se baseia, pelo menos em parte, na preocupaçáo em dotar de sentido e de extrair uma lógica ao mesmo tempo retrospectiva e prospectiva, atribuindo inteligibilidade aos percursos e percalços de uma vida. Apesar do alerta de Bourdieu de que a produção de uma história de vida (tratando um conjunto heterogêneo de acontecimentos e acasos como um relato coerente de uma sequência de episódios com significado e direção) talvez seja uma forma de conformar-se com uma ilusão retórica, acreditamos que a presente entrevista nos possibilita enfrentar essa armadilha biográfica, na medida em que a trajetória de um autor não expóe apenas os caminhos percorridos ao longo de uma vida, mas pode nos apresentar 
um retrato de um momento particular de uma área do conhecimento e de seus debates candentes.

Ao ler a entrevista, me parece claro que esta trata não somente da trajetória de vida e acadêmica do pesquisador, mas retrata algumas das questóes e preocupaçóes que levaram a antropologia a algumas viradas e a um novo momento, se ausentando dos domínios exclusivos da religião para questionar as formas do secular, deixando de privilegiar uma antropologia do simbólico para focar no corpóreo, sensório, ético e estético, e, mais recentemente, retomando temas clássicos, como a relação entre antropologia e história, a partir de um novo olhar. Assim, a Debates do NER convida seus leitores a embarcar nessa jornada pela trajetória de Charles Hirschkind, assim como nos trajetos do pensamento antropológico contemporâneo.

\section{REFERÊNCIAS}

BOURDIEU, Pierre. L'illusion biographique. Actes de la Recherche en Sciences Sociales, v. 62-63, p. 69-72, jun., 1986.

HIRSCHKIND, Charles. The Ethics of Listening: Cassette Sermon Audition in Contemporary Egypt. American Ethnologist, v.28 (3), pp. 623-649, 2001. HIRSCHKIND, Charles. The Ethical Soundscape: Cassette Sermons and Islamic Counterpublics. New York: Columbia University Press, 2006.

HIRSCHKIND, Charles. The Feeling of History: Islam, Romanticism, and Andalusia. Chicago: University of Chicago Press, 2020.

Recebido em: 24/03/2021

Aprovado em: 24/03/2021 
